\title{
The Effect of Headmaster Leadership and Organizational Climate on Teacher Success in SMP Negeri Mekakau Ilir District
}

\author{
Mat Azwar ${ }^{1 *}$, Yasir Arafat ${ }^{2}$, Yenny Puspita ${ }^{2}$
}

\author{
${ }^{1}$ SMP Negeri 1 Mekakau Ilir \\ ${ }^{2}$ Universitas PGRI Palembang, Indonesia \\ *Corresponding author. Email: azwardapa07@gmail.com
}

\begin{abstract}
The focus of this research is to analyze the effect of main leadership and school organizational climate on the quality of teachers in the SMP Negeri Mekakau Ilir District. This methodology is a primary data of quantitative research. The findings showed there was a substantial effect of head teachers and school organizational climate upon this quality of teachers in the SMP Negeri Mekakau Ilir District. It can therefore be established that the key leadership factors and the organizational climate of the institution require attention. The school's success is solely in the hands of the leader. The Principal must be able to handle school administration well so that educational objectives can be accomplished in schools. Strong leadership is the leading of a headmaster who is capable of performing administrative duties, supervisory duties and entrepreneurial growth tasks in his school. The leadership of the principal, carried out in conjunction with their key duties as principal of the school, and followed by a good situation and condition of school organization in the climate, would be essential to the achievement of educators in their schools.
\end{abstract}

Keywords: Leadership, School Principal, Organizational Climate, Success of Teachers

\section{INTRODUCTION}

Our school reform policy legislation specifically notes that the national education system must be able and guaranteed to increase the quality and importance and efficacy of education management in order to meet the demands of the times and rapid changes in life both locally, nationally and globally. Education must therefore always be renewed in a scheduled, targeted, continuous and sustainable manner. Education is the most key factor for the growth of a nation [1].

Schools are at the forefront of ensuring the enhancement of the standard of education in Indonesia in order to meet the mandate of the national education system referred to above. This is in line with the view of Murtiningsih and Lian [2] that school is the most important world of education.

The pressures and burdens for schools will be higher in the future, along with accelerating the advancement of science and technology. If schools are unable to keep up with these changes, the standard of our education will be gradually left behind from other countries. This is in line with what Japanese Prime Minister Sinzo Abe said at the World Enonomical Forum in Davos in
January 2019 that the world is currently facing an industrial 4.0 revolution marked by the advent of supercomputers, smart robots, driverless cars, cloud computing, big data systems, genetic engineering and neurotechnology innovations that allow humans to do so.

Moreover, Sinzo Abe added that the next step would be the 5.0 age, a human-centered society that combines economic and technological development by solving problems through a framework that incorporates the virtual world and physical space, where human functions are replaced by the existence of robots - smart robots. A community that can overcome multiple issues and societal problems by using different technologies is the key aspect of society 5.0.

School is an academic institution that has a vision, a mission and a goal. Modern schooling carries the fate of accountability for destructive developments in the moral and spiritual domain of humanity [3]. The school is often made up of different elements involved in it. These different elements work hand in hand to achieve the school's vision, purpose and objectives. The members of the school association include principals, 
educators or teachers, instructional or administrative personnel, school boards, parents of students, students and the local community. School organization wheels will turn rapidly and instantly hit the finish line, if the above components work well together.

The principal and the teaching council are the most critical elements in the organization of the school. If the Principal and the Teacher Council work together effectively, harmoniously and in a constructive manner, then the organizational environment of the school is also generally well-functioning. The principal as the leader has the authority and policy to improve the quality of education [4].

Schools should be led by a principal who genuinely respects and is willing to strengthen the professionalism of teachers and the standard of school education. This is in line with the guidance of the Director-General of GTK, Ministry of Education and Culture [5], which notes that the Principal as a Leader must be able to promote the emergence of a strong will with complete enthusiasm and trust in the Board of Teachers, Teachers and Students. The Principal must also be able to give instruction, guidance, support, inspiration to teachers, educators and students and be at the forefront of quality education in schools. The Principal should be able to perform imagination, to lead both participants and the school as an educational institution to change their minds, to establish their vision and mission by using the strengths, skills and capacities of its [6].

In addition, the Director-General of GTK, Kemendikbud [5], argues that, in order to achieve the standard of education in schools, the school principal must master strategies in the performance of his position as school principal. The Principal must have the right approach to enhance the professionalism and success of teachers and school employees. The Principal must also be able to inspire teachers and staff through cooperative collaboration and provide them with opportunities to develop their professional skills and promote their participation in various school events that support school objectives.

The Leader should have a very good and respectful relationships with the different parties, often develop two-way contact and assign tasks to teachers and staff in a proportionate manner. The school principal must also be in a position to provide guidance and guidance, as well as inspiration for the entire board of teachers and instructional staff to carry out different duties and functions. The Principal must be a role model that can be used as an example for the entire Board of Teachers, Teachers and Students. In order to improve the performance of teachers and educational staff, the Principal must also always exercise supervision and control. The theory must also have a strong stance when it comes to making policy decisions.
In Permendikbud No. 6 of 2018 [5] it is reported that the principal is a teacher whose job is to lead and manage a school or educational unit. It is mentioned that the workload of the Principal consists of the key tasks, i.e. the management tasks, the supervision of teachers and training staff, as well as the tasks of entrepreneurial growth. These key tasks will be measured on a periodic basis each year in the form of an evaluation of the principal's performance of work, including the priorities, actions and attendance of employees. The evaluation of the job performance of the head teachers shall be conducted out through direct superiors, which shall include a number of components, such as the assessment of the results of the implementation of the management tasks, the assessment of the results of the entrepreneurial development, the assessment of the results of the supervision of the educators and the training staff, and the assessment of the results of the training.

In addition, everything is included with the evaluation of the actively developing of the school principal's management activities includes the assessment of school program preparation, the management, tracking and review, and management of information systems. In the meantime, the assessment of entrepreneurial growth consists of an assessment of entrepreneurial development preparation, an assessment of the execution of the development of entrepreneurship and an evaluation of the development of entrepreneurship. In the meantime, what is included in the evaluation of teacher supervision and discipline consists of an assessment of teacher preparation and supervision of staff, an assessment of the application of teacher supervision and education management, and an evaluation of the application of teacher supervision and supervision of staff [5].

From the above explanation, it can be inferred that the professional leadership of the principal is the leadership of the principal, who is in a position to execute his key duties properly in compliance with the guidelines mandated by statute. Strong leadership is the leadership of the principal who is capable of fulfilling administrative duties, supervisory duties and entrepreneurial growth tasks.

Apart from the principal, one aspect of the school that plays an important role in achieving the educational objectives of the school is the teacher. Teachers are important players in ensuring that the standard of education in schools is improved. If the quality of an educator is poor, it will automatically have an effect on the standard of school education. Improving teacher efficiency is therefore a crucial factor that needs to be brought to the attention of the government.

According to Permenpan RB No. 16 of 2009 on teacher functional roles and credit ratings, the key role of teachers is to educate, guide, teach, direct, assess, train and evaluate students. In the meantime, what is 
meant by the teacher performance evaluation is an assessment of and activity item of the key tasks of the teacher listed above.

In the meantime, on the basis of Permendiknas number 16 of 2007 on academic qualification requirements and teacher competence, it notes that a teacher must have pedagogic competence, personality competence, technical competence and social competence. In addition, Permendiknas No. 35 of 2010 on the Technical Guidance for the Implementation of Teachers' Functional Roles and Credit Figures states that the concept of teacher performance evaluation is based on the skill of the teacher referred to above.

As per Permendiknas Number 35 of 2010 on professional guidance for the performance of teaching positions and credit statistics, the basis for assessing the performance of teachers is connected to aspects of the execution of the main duties of teachers, including: 1) the performance of the instructor related to the implementation of the learning activity process, namely the preparation and implementation of the learning, review, assessment, interpretation and follow-up of the results of the assessment; 2) the performance of the instructor related to the guidance process, which involves preparing and performing guidance exercises, reviewing and evaluating the results of the guidance, analyzing the results of the assessment and implementing a follow-up on the results of the guidance, and 3) teacher success relates to other duties important to school functions, such as being the principal, the vice-principal, the head of the curriculum, the head of the library, the head of the laboratory, the home teacher, the review supervisor, the supervisor of the scientific articles, the head of the workshops and the head of the development units.

On the basis of the above definition, a teacher must have an evaluation of the performance of the teacher in carrying out his main task with a minimum category of good. So that the teacher can be said to be a competent and worthy teacher to carry out activities to educate, guide, instruct, lead, assess, train and evaluate students in their school. If the performance assessment of teachers is successful, it would have an impact on improving the standard of education in these schools.

From the above explanation, it can be inferred that the leadership of the Principal, carried out in conjunction with the key duties of the Principal, would be able to enhance the performance of the Teacher.

This is also supported by the research findings of Maryani et al [7] that the leadership style of the Principal has an effect on the success of teachers in the Ogan Ilir Children's Garden.

In this case, the author has carried out the activities of gathering data and preliminary information on this study, namely through interviews with the vice-principal of the school, several teachers and a number of educational staff. Thus, on the basis of these preliminary results, a number of problems have been established, including those related to the main duties of the school principal, namely the supervision of teachers and educational staff, and it has been found that there have been principals who have not and seldom carried out evaluations of the supervision of teachers and staff in the form of: a). Planning for the supervision of teachers and training workers, b). Implementation of supervision of teachers and workers of education, as well as (c). Evaluation of the supervision of teachers and employees of education.

In relation with the main tasks of the Principal, namely the management appraisal of the Principal, in the context of the constant creation of exemplary programs of attitudes and actions that preserve the good reputation of the institution, the profession and the place, in terms of attendance at school, the Principal frequently comes late to school. This causes the time of the principal to decrease in the school setting. If any of this continues, it is somewhat contradictory to the key duties of the school principal, which allows the principal to always cultivate an exemplary program of attitudes and conduct that preserves the good reputation of the college, the profession and the position/position, and also contradicts the characteristics of the competent school principal, which is always devoted much of its time to work in the institution.

In combination with the key duties of the Principal, namely the management appraisal of the Principal, in order to always make decisions on the school budget by considering the input of teachers and school committees, the Principal tends to be closed and never includes teachers and education staff and school committees.

In accordance with the key tasks of the Principal, namely the management assessment of the Principal in the field of supervision and evaluation, one of which is to always plan for and follow up school accreditation, information was therefore obtained that, in 2019, one school had participated in school accreditation activities, but the results of the assessment had decreased. As a result, it can automatically be inferred that there has been a deterioration in efficiency, both in terms of school eligibility metrics and the performance of school members, including the performance of school principals.

In addition to the elements of school principals and teachers as the key players in improving the standard of education in schools, the climatic conditions of the school organization are one thing that is critical and that defines the quality of school improvement. Sometimes in school, there are teachers who have high values and good quality education, but because of the state of the 
school organization, the environment is not good and the performance of the teacher is poor.

So according Asmani [8], school organizations have a very important role to play in enhancing the quality of school education. All school events, both intracurricular and extra-curricular, are planned and driven by the school organisation. If the school organization works effectively, all operations in the school will therefore be carried out effectively. The efficacy of school organizations can also be seen from the organizational structure of schools, job programs, processes, consolidation, communication, education, teamwork and synergy. The effectiveness of school organizations is therefore primarily determined by a structure that gives priority to democracy, engagement, stabilization, harmony and dynamism.

In addition, Asmani [8] notes that school associations should be set up to fulfill the school objectives decided upon by school principals, teachers, students, parents of students, community leaders and local governments. All components must be involved in all processes within the school organisation, beginning with the planning, execution, organization, control and proactive critical assessment processes for the continuous development of the school organisation. If the speed of school organization is not at hand, even good school programs can run on the ground halfway and the aims of school organization cannot be accomplished. This is where the importance of promoting and mobilizing school organizations to ensure that the life of the school continues and continues. Skilled school principals who recognize school organizations are required to revive school organizations.

Asmani [8] concludes that an organizational approach to school management is very important. Since, until now, we still have many schools that still use conventional approaches and patterns that are centralistic, paternalistic, bureaucratic, patriarchal and hegemonic. These trends and practices are, of course, somewhat contrary to the school organization strategy, which gives priority to the design of school programs, school budgets, organizational processes, program execution, program assessment and follow-up of school programs.

From the above explanation, it can be inferred that the leadership of the Principal, which is carried out in accordance with the key duties of the Principal and followed by the circumstance and conditions of a successful school organization, would be able to enhance the performance of the faculty.

A number of studies related to school leadership, school organizational environment and teacher performance have shown that primary leadership and school organizational climate have a partnership, impact and contribution to teacher performance. The relationship between headmaster leadership, school organizational environment and teacher performance is demonstrated by research conducted by Suriyanto in 2014, which shows that there is a major impact of primary leadership and school organizational climate on teacher performance in sub-ray 6 junior high school, Seluas District, Bengkayang Regency. This is also supported by the research findings of Maryani, et al [7] that the leadership style of the Principal has an effect on the success of teachers in the Ogan Ilir Children's Garden.

On the basis of the above issues, the authors will carry out research on "The Effect of Headmaster Leadership and Organizational Climate on Teacher Success in SMP Negeri Mekakau Ilir District “.

\section{METHODS}

The site where this research was performed in all SMP Negeri in Mekakau Ilir Subdistrict, Ogan Komering Ulu Selatan Regency, consisting of SMP Negeri 01 Mekakau Ilir, SMP Negeri 02 Mekakau Ilir and SMP Negeri One Atap Sri Menanti.

The approach used in this study is a descriptive quantitative research method, i.e. a research method based on the theory of positivism, used for population or sample research, sampling techniques are usually carried out randomly, data collection uses research instruments, data analysis is quantitative/statistical with the goal of testing the hypothesis that has been developed [9]. Methodology would be a determining factor in the merits of the writing of scientific papers [10]. The data collection of the study was carried out using a questionnaire, and the data were analyzed quantitatively.

Although this form of study is a quantitative method of research using a survey method. According to Sugiyono [9], the survey approach is used to acquire data from such natural (not artificial) sites, but researchers handle data collection, e.g. by distributing questionnaires, assessments, standardized interviews, and so on (treatment is not like experiments).

Thus, this research method is a quantitative research method with the goal of understanding the relationship between variables using quantitative data on the impact of school leadership and school organizational environment on teacher performance at SMP Negeri in Mekakau Ilir District, Ogan Komering Ulu Selatan Regency.

As per Sugiyono in Kesumawati, Retta and Sari [11] the population is a generalization region made up of objects or subjects that have certain qualities and characteristics decided by the researchers to be examined and then to draw conclusions. The population 
is a group in a field of study that is used as an example of sampling. The population of this study was all the teachers of the SMP Negeri Mekakau Ilir District, Ogan Komering Ulu Selatan District.

According to Sugiyono in Kesumawati, Retta and Sari [11], the sample is part of the number and characteristics of the population. A saturated sampling technique will be used in this analysis, based on the number of teachers of the SMP Negeri Mekakau Ilir District. According to Sugiyono [9] the saturated sampling technique is a sampling technique where all members of the population are used as samples, often when the population is relatively small.

Table 1. The sample size of the analysis

\begin{tabular}{|l|l|c|l|l|c|c|c|}
\hline \multirow{2}{*}{ No } & Name of School & \multicolumn{2}{|c|}{ Population } & \multicolumn{3}{c|}{ Sample } \\
\cline { 2 - 8 } & $\begin{array}{c}\text { Number } \\
\text { of } \\
\text { Teachers }\end{array}$ & $\mathrm{M}$ & $\mathrm{F}$ & $\begin{array}{c}\text { Number } \\
\text { of } \\
\text { Teachers }\end{array}$ & $\mathrm{M}$ & $\mathrm{F}$ \\
\hline 1 & SMP N 1 Mekakau Ilir & 33 & 9 & 24 & 33 & 9 & 24 \\
\hline 2 & SMP N 2 Mekakau Ilir & 19 & 4 & 15 & 19 & 4 & 15 \\
\hline 3 & $\begin{array}{l}\text { SMP N Satap Sri } \\
\text { Menanti }\end{array}$ & 21 & 11 & 10 & 21 & 11 & 10 \\
\hline & Jumlah & $\mathbf{7 3}$ & 24 & 49 & 73 & & 49 \\
\hline
\end{tabular}

Source: Decree on the division of tasks for SMP Negeri District of Mekakau Ilir odd semester 2020/2021 school year

Checking the instrument using the Construction Test, Validity Test and Reliability Test. The build test uses the process by which the research instrument is submitted to the experts to be corrected, and the research instrument has been submitted to the experts to be corrected, namely Dr. Happy Fitria, M.Pd, Dr. Syaiful Eddy, M.Si and Dr. Achmad Wahidy, M.Pd.

The validity and reliability of the instrument was tested on 30 respondents who were not included in the study sample. Based on the test of the instrument, it was concluded that all the statements in the research instrument were true and accurate.

\section{RESULTS AND DISCUSSION}

Based on the results of the Hypothesis Testing, the leadership component of the Principal received a value of 0.000 and a count of 6.450 . The significance value of 0.000 turns out to be less than the normal significance value of 0.05 , so the argument reads $0.000<0.05$. In addition, based on the t-count value, the value is 6,450 and, when compared with the t-table distribution value, the number is 1,994 . The sentence reads, therefore, that the value of tcount $(6,450)$ is greater than the value of ttable $(1,994)$ or $6,450>1,994$. This indicates that there is a major impact of the principal's leadership variable on the success variables of the instructor.

Based on the results of the test, the F-test hypothesis obtained a value of 0.000 and the F-test is obtained for 640,467 . The significance value of 0.000 turns out to be less than the normal significance value of 0.05 , so the argument reads $0.000<0.05$. In addition, on the basis of the value of the Fcount, a value of 640,467 is obtained and, after being compared with the value of the Ftable distribution, that amount is 3,126 . Thus, the statement notes that the value of Fcount $(640,467)$ is greater than the value of Ftable $(3,126)$ or $640,467>3,126$.

Based on the findings of the estimation of the School Organization Environment Variable $\left(\mathrm{X}_{2}\right)$ hypothesis, a value of 0.000 was obtained and the count was 8.333. The significance value of 0.000 turns out to be less than the normal significance value of 0.05 , so the argument reads $0.000<0.05$. In addition, based on the tcount value, the value is 8,333 and the t-table distribution value is 1,994 . Thus, the argument notes that the tcount value $(8,333)$ is greater than the table value $(1,994)$ or $8,333>1,994$. This indicates that the effect of the school environment variable organization $\left(\mathrm{X}_{2}\right)$ on the output variable of the instructor is important $(\mathrm{Y})$.

\section{CONCLUSION}

On the basis of the above definition, the findings of this study can be inferred as follows: there is a major impact on the performance of the principal leadership of the instructor. This can be seen from the results of the $t$ measure, which has a value of 0.000 and a tcount of 6.450. There is also an important influence on teacher success of the school's organizational environment. This can be seen from the value of 0.000 and the figure of 8.333. There is also a major impact of the Principal's leadership and school organizational environment on the performance of teachers at SMP Negeri Mekakau Ilir, where the results of the F-test were 0.000 and the F-test was 640,467 . On the basis of the above explanation, it can be inferred that the leadership of the Principal $\left(X_{1}\right)$ and the school organizational environment $\left(\mathrm{X}_{2}\right)$ have a major impact on the teaching 
output (Y) of the SMP Negeri Mekakau Ilir District, Ogan Komering Ulu Selatan Regency.

\section{AUTHORS' CONTRIBUTION}

Mat Azwar: designed and performed experiments and analysed data. Yasir Arafat and Yenny Puspita: correcting and revising.

\section{ACKNOWLEDGMENTS}

Thank you very much to the Principal and Teacher Board of SMPN 01 Mekakau Ilir, SMPN 02 Mekakau Ilir and SMPN one roof of Srimenanti. It was also forwarded to the Chancellor, Postgraduate Director, Head of Education Management Study Program, Advisor I, Supervisor II and all postgraduate lecturers at PGRI Palembang University. Also, for all fellow graduate students of PGRI Palembang University. Thank you for helping to complete this journal, which is the result of the preparation of the thesis as a prerequisite for the final report. Please criticize and recommend to develop this journal.

\section{REFERENCES}

[1] Asvio, N., Yamin, M., \& Risnita. (2019). Influence of Leadership Style, Emotional Intelligence and Job Satisfaction toward Organizational Commitment (Survey at SMA Muhammadiyah South Sumatera). International Journal of Scientific \& Technology Research 8 (8).

[2] Murtiningsih \& Lian, B. (2017). Proses Pengambilan Keputusan Kepala Sekolah terhadap Peningkatan Kinerja Guru SMP [Decision Making Process for Principals on Improving Junior High School Teacher Performance]. Manajemen, Kepemimpinan dan Supervisi Pendidikan, volume 2 (1): halaman 87-96.

[3] Maseleno, A., Ayshwary, B., Ivanova, T. N., Hashim, W., Nguyen, P. T., Shankar, K., Kristiawan, M., Huda, M. (2019). General Theoretical and Philosophical Aspects of Modern Education. Aspectos Teóricos y Filosóficos Generales de la Educación Moderna. Revista San Gregorio 2019, No. 32 Special Issues August.

[4] Tobari., Kristiawan, M. \& Asvio, N. (2018). The Strategy of Headmaster on Upgrading Educational Quality in Asean Economic Community (AEC) Era. International Journal of Scientific \& Technology Research 7 (4).

[5] Kemdikbud. (2018. Formulir Penilaian Kinerja Kepala SMP [SMP Principal Performance Assessment Form]. Jakarta: Dirjen GTK.
[6] Andriani, S., Kesumawati, N., \& Kristiawan, M. (2018). The Influence of the Transformational Leadership and Work Motivation on Teachers Performance. International Journal of Scientific \& Technology Research, 7(7).

[7] Maryani., Lian, B., \& Wardarita. (2020). Pengaruh Gaya Kepemimpinan Kepala Sekolah dan Budaya Organisasi Sekolah terhadap Kinerja Guru [The Influence of Principal Leadership Style and School Organizational Culture on Teacher Performance]. Journal of Innovation in Teaching and Instructional Media. Volume 1 (1) 18-25.

[8] Asmani., \& Ma'mur, J. (2012). Tips Efektif Supervisi Pendidikan Sekolah [Effective Tips School Education Supervision]. Yogyakarta: Diva Press.

[9] Sugiyono. (2008). Metodologi Penelitian [Research Methodology]. Yogyakarta: Diva Press.

[10] Muttaqin, K., \& Rahmadoni, J. (2020). Analysis And Design of File Security System AES (Advanced Encryption Standard) Cryptography Based. Journal of Applied Engineering and Technological Science (JAETS), 1(2), 113-123. https://doi.org/10.37385/jaets.v1i2.78

[11] Kesumawati, N. et al. (2019). Pengantar Statistika Penelitian [Introduction to Research Statistics]. Depok: PT. Raja Grafindo Persada. 